\title{
Antidiabetic and Antihypertensive Properties of Chymotrypsin Treated Cow Milk Casein
}

\author{
Santosh Kumar ${ }^{1 *}$, SumanKumari², Vipan Kumar $^{3}$ and Deepak Kumar ${ }^{4}$ \\ ${ }^{1}$ MDETT Research Center, BAIF Development Research Foundation, \\ Dharoli, Jind - 126113 (Haryana), India \\ ${ }^{2}$ Dolphin PG Institute of Biomedical \& Natural Sciences, Dehradun (Uttarakhand), India \\ ${ }^{3}$ Department of Veterinary Microbiology, Khalsa College of Veterinary and Animal Science, \\ Amritsar (Punjab), India \\ ${ }^{4}$ Department of Pharmaceutical Chemistry, Dolphin PG Institute of Biomedical \& Natural \\ Sciences, Dehradun (Uttarakhand), India \\ *Corresponding author
}

\section{Keywords}

Angiotensin converting enzyme(ACE), Amylase, Antihypertensive, Imunomodulation, Biogenic peptides

\section{Article Info}

Accepted:

18 May 2020

Available Online:

10 June 2020

\begin{abstract}
A B S T R A C T
Milk is known to contain a number of peptides fractions that affect metabolic responses. Casein being the most abundant milk protein, after enzymatic treatment generates peptide fragments which have unique ability to regulate the diabetic and hypertensive metabolic pathways in the biological system. Upon oral administration of bioactive peptides may affect the major body system-namely the cardiovascular, digestive, immune and nervous systems showing multiple biogenic effects such as antimicrobial, Immuno modulatory, antioxidative, antithromboic, antidiabetic and antihypertensive. In the present study, the peptide formulation derived from chymotrypsin treated cow milk casein was functionally studied for their antidiabetic (via $\alpha$-amylase inhibition) and antihypertensive (via angiotensin converting enzyme inhibition) activity. The peptide content and their biogenic effects varies with the duration of enzymatic treatment thus depicting variable effects. Maximum antidiabetic effect was shown by bioactive derived after 3 hours of enzymatic treatment; while maximum antihypertensive effect was shown by bioactive derived after 6 hours of incubation with chymotrypsin. These metabolic effects of these unique peptide formulations were required to be explored for their targeted use as nutritional supplements for diabetic and hypertensive patients.
\end{abstract}

\section{Introduction}

Milk is a well-balanced source of nutrients which exhibit diverse biological activities influencing digestion, metabolic response to absorbed nutrients growth and development of specific organs and is resistance to disease. Biological activities are mainly due to the peptides and protein in milk (FitzGerald and Meisel,2003;Korhonen and pihlanto,2003). Enzymatic degradation of food stuffs in the gut release short chain peptides sequences 
from intact proteins, glycoprotein \& lipoprotein. In many cases, peptides liberated in this fashion can have important biogenic fashions (Schlimme\&Meisel, 1995).Bioactive peptides are produced during enzymatic catabolism of milk in the gastrointestinal tract. These specific protein fragments have a positive impact on body function or conditions ultimately influencing health (Kitts \& Wailer, 2003).Bioactive peptides, may affect the major body system-namely, the cardiovascular, digestive, and immune and nervous system. Its beneficial health effects may be classified as antioxidative, antihypertensive, antidiabetic affect, immuno modulatory (Korhonenand Philanto, 2006). These nutrients influence digestion, metabolic responses to absorb nutrients, growth and development of specific organs and resistance to disease. These biological activities are mainly due to the peptides and protein in milk. However, some of the biological activity of milk protein components is latent and is during digestion of milk in the gastrointestinal tract and also during fermentation and food processing. At present, milk proteins are considered the most important source of bioactive peptides.

Cow milk is an important food with many nutrients. The precise nutrient composition of fat,protein and calcium as well as vitamin $\mathrm{C}$. Cow's milk has a $\mathrm{pH}$ ranging from 6.4 to 6.8 ,making it slightly acidic. Milk contains an array of bioactivities which are due to minor proteins and peptides secreted into milk in active form by the mammary gland, in addition to these fully active components, many bioactive peptides from milk proteins act as precursors (Meisel, H., 1998). Casein is the main proteinaceous component of milk, where it accounts for $80 \%$ of the total protein inventory. Until recently, the main physiological role of casein in the milk system was widely accepted to be a source of amino acids required by growth of the neonate. Dietary protein is partially digested in the stomach and small intestine via the successive action of hydrochloric acid.

Presently, hypertension being one of the major risk factor for cardiovascular disease and stroke, diet and nutritional supplements are of considerable interest for researchers because it has an influential role in the prevention and treatment of this disease. Therefore, to develop foods with antihypertensive activity, ACE, a multifunctional coenzyme, participating in angiotensin regulation is targeted. This enzyme is a glycoprotein, zincmetalloprotease, a multifunctional acetoenzyme found in lungs, endothelial cells and plasma. It removes 2carboxyl the rest of 8 amino acids and is termed Angiotensin-II (FitzGerald\&Meisel, 2000). It plays important role in blood pressure regulation and in turn hypertension.

Therefore, ACE inhibition mainly results in a hypotensive effect. Most of the reported ACE inhibitory peptides are also short peptides with a Pro residue at the carboxyl(C)-terminal end. The Pro residue at the C-terminus seems to have an important structural function in expressing strong inhibiting activity against ACE. Moreover, a short peptide is more readily absorbed from the gastrointestinal tract (Yamamoto et al., 2003).

The ACE hydrolyses largely inactive angiotensin-I to the octapeptides angiotensinII, which increase blood pressure. This enzyme also hydrolyses bradykinin, which is a hypotensive. Thus inhibitory are antihypertensive peptides. Angiotensin-II,a product of ACE activity an angiotensin-I, is one of the most powerful vasoconstrictor substance known (Collins et. al., 1990).

The most common way to produce bioactive peptides is through enzymatic hydrolysis of whole protein molecules. Many of the known bioactive-peptides have been produced using gastrointestinal enzymes. In the earlier 
studies, microbial strains secreting catabolic enzymes have been used for casein hydrolysis.

The immunomodulatory activities of cow milk casein have been studied earlier (Cross and Gill, 2000) butthe role of casein hydrolysates as antidiabetic and antihypertensive agents are still under primitive stage of investigation till now. Henceforth, in the present work, the impact of enzymatic treatment on antidiabetic and antihypertensive properties was evaluated. Comparative studies of regulatory effects of casein hydrolysate formulations, formed after variable enzymatic treatments, were conducted.

The metabolic activities of the casein peptides were verified using purified enzymatic inhibition studies. The regulatory enzyme inhibition led us to conclude a positive correlation with the role of casein peptides in modulating the diabetic and hypertensive metabolic pathways in the biological system. Purified enzymes were used for the investigation to clearly observe the direct impact on the diabetes and hypertension related bioprocesses. In the current study, the effect of chymotrypsin treatment was also investigated on the casein hydrolysates and their effects on regulatory metabolic enzymes were further analyzed.

\section{Materials and Methods}

\section{Preparation of casein}

Cow milk sample were collected from available breeds of cow in the locality of Suddhowala, Dehradun, India. Casein was prepared from cow milk using the method of iso-electric precipitation. Briefly, $500 \mathrm{ml}$ milk, immediately after collection, was defatted by centrifuging twice at $5000 \mathrm{~g}$ for 20 min at $4^{\circ} \mathrm{C}$ in a refrigerated centrifuge. The filtrate was diluted with equal volume of double distilled water (DDW); $\mathrm{pH}$ adjusted to 4.6 with $1 \mathrm{~N} \mathrm{HCl}$ and the mixture was stirred for $20 \mathrm{~min}$.

The precipitate so formed was separated by filtration through four layer of cheese-cloth, washed, solubilized in distilled water at $\mathrm{pH}$ 7.0 (equal to initial volume of milk) with $1 \mathrm{~N}$ $\mathrm{NaOH}$, reprecipitated and washed 3-4 times with distilled water. The wet casein after thorough washing with distilled water was dried at room temperature for 28 hours to obtain a dry powder.

\section{Preparation of sodium caseinate}

Dried casein was solubilised in distilled water $(3 \mathrm{gm} / 50 \mathrm{ml})$ by continuous stirring with the help of magnetic stirrer and simultaneous addition of $0.1 \mathrm{~N} \mathrm{NaOH}$ drop wise so as to obtain $\mathrm{pH}$ of this homogenous solution to 7.2. The final volume was made up to $100 \mathrm{ml}$ with double distilled water. The solution of sodium caseinate was stored at $4^{\circ} \mathrm{C}$, till it was processed for further studies. The concentration of protein in various samples was estimated by using the method of Lowery et al., (1951).

\section{Treatment with proteolytic enzyme}

Casein prepared isoelectrically was treated with Chymotrypsin enzyme according to the method suggested by Abubakar et al., (1998) \& Pihlantoleppala et al., (2000). Briefly, $0.113 \mathrm{~g}$ of casein was taken containing $100 \mathrm{mg}$ of protein was dissolved in $20 \mathrm{ml}$ ammonium acetate buffer $(0.02 \mathrm{M} \mathrm{pH} 8.0)$. To this $1 \%$ chymotrypsin solution was added and stirred at $25^{\circ} \mathrm{C}$ for $60,120,180,240,300$ and $360 \mathrm{~min}$. The enzyme substrate ratio was maintained at 1:100. After variable incubation periods, enzyme activity was stopped by heating at $100^{\circ} \mathrm{C}$ for $5 \mathrm{~min}$. The supernatant and pellet was separated by the process of centrifugation at $10,000 \mathrm{rpm}$ for $20 \mathrm{~min}$ and supernatant stored at $4^{0} \mathrm{C}$ in a deep freezer. 
Estimation of partial hydrolysis of protein by hull's method

\section{Tyrosine standard curve}

A stock solution of tyrosine of $0.2 \mathrm{mg} / \mathrm{ml}$ was prepared. Different concentrations ranging from $100 \mu \mathrm{g}$ to $1000 \mu \mathrm{g}$ were taken. The volume was made upto $6 \mathrm{ml}$ with double distilled. To these samples was added $10 \mathrm{ml}$ of $0.72 \mathrm{~N}$ TCA and were kept at $37^{\circ} \mathrm{C}$. For 15 min in $5 \mathrm{ml}$ of this aliquot, $15 \%$ sodium carbonate in $0.1 \mathrm{~N} \mathrm{NaOH}-\mathrm{CopperSulphate}$ solutions was added and mixed thoroughly. Finally $3 \mathrm{ml}$ of Folin's Reagent was added. This mixture was kept in dark for 5-10 min for color development. The blue color thus development was measured at $650 \mathrm{~nm}$. A standard curve plotting tyrosine concentration against O.D. at $650 \mathrm{~nm}$ was prepared.

\section{Quantification of enzyme hydrolysate}

$0.1 \mathrm{ml}$ of the supernatant samples (from different incubation time periods) were taken in test tubes and the volume was made up to 6 $\mathrm{ml}$ with distilled water. To this $10 \mathrm{ml}$ of 0.72 $\mathrm{N}$ TCA was added to precipitate the protein present, if any, after allowing them to stand for $15 \mathrm{~min}$ at $37^{\circ} \mathrm{C}$.

The contents were filtered through fat free Whattman filter paper. To $5 \mathrm{ml}$ of filtrate, 10 $\mathrm{ml}$ of $15 \%$ sodium carbonate in $0.1 \mathrm{~N} \mathrm{NaOH}$ was added \& mixed thoroughly. Then, $3 \mathrm{ml}$ of Folin Ciocalteau's reagent was added. After allowing the tubes to stand in dark for 5-10 min the absorbance was measured at $650 \mathrm{~nm}$.

\section{Assay of antidiabetic activity by $\alpha$-amylase} inhibition

In monosaccharide glucose can be readily absorbed from the gastrointestinal tract into the blood stream after the hydrolysis of glycosidic bonds by the enzyme $\alpha$-amylase and $\alpha$-glucosidase in digestible carbohydrate foods. The bioassay method was adopted and modified from Sigma-Aldrich technical documents protocols. A starch solution $(0.5 \%$ w/v) was added in $25 \mathrm{ml}$ of buffer $(20 \mathrm{Mm}$ sodium phosphate buffer with $6.7 \mathrm{Mm}$ sodium chloride, pH6.9). The enzyme solution was prepared by mixing of $\alpha$-amylase solution $(1 \mathrm{U} / \mathrm{ml})$. The calorimetric reagent was prepared mixing sodium potassium tartrate solution and $96 \mathrm{Mm} \mathrm{3,5-dinitrosalicylic} \mathrm{acid}$ solution $1: 1(\mathrm{v} / \mathrm{v})$.Both sample and control $(40 \mu \mathrm{l})$ were added to starch solution $(400 \mu \mathrm{l})$ and left to react with $\alpha$-amylase solution $(200 \mu \mathrm{l})$ in alkaline condition at $25^{\circ} \mathrm{C}$. Acarbose was used as positive control. The reaction was measured over $3 \mathrm{~min}$ and the generation of maltose was quantified by measuring the absorbance at $540 \mathrm{~nm}$ of 3amino -5-nitrosalicylic acid, the product formed due to reduction of 3,5 dinitrosalicylic acid. In the presence of $\alpha$ amylase inhibitor, less maltose would be produced and the absorbance value will increase. Each sample assay is carried out in triplet and result was represented as a mean of three values \pm Standard Deviation. The enzyme inhibition was estimated as \% inhibition

Reaction rate $(\%)=\frac{\underline{A}_{t}}{A_{c}} \times 100$

Inhibition $(\%)=100-$ Reaction $\operatorname{rate}(\%) \pm$ S.D

Where $A_{t}$ is the absorbance of test sample, $A_{c}$ is the absorbance of Control sample and S.D. =Standard Deviation.

\section{Angiotensive converting enzyme (ACE) inhibition assay}

Angiotensive converting enzyme(ACE) inhibition was measured as suggested by Cushman and Cheung (1971) and modified by Hernandez-Ledesmanet. al.(2003).Briefly, 
$15 \mu 1$ of hydrolysate was added to $110 \mu 1$ of substrate (10Mm Hippuryl-L-Histidyl-LLeucine in $0.1 \mathrm{M}$ borate buffer containing $0.3 \mathrm{M}$ molar $\mathrm{NaCl}, \mathrm{pH} 8.3$ ), and mixed at $37^{\circ} \mathrm{C}$. Then, $25 \mu \mathrm{l}$ of Angiotensin Converting Enzyme $(0.2 \mathrm{U} / \mathrm{ml})$ was added and incubated at $37^{\circ} \mathrm{C}$ for 80 minute. Reaction was stopped by $200 \mu \mathrm{l}$ of $1 \mathrm{~N} \mathrm{HCl}$.

Subsequently the hippuric acid formed in the enzymatic process was extracted with $1 \mathrm{ml}$ of ethyl acetate (by centrifugation at 3,000xg for $10 \mathrm{~min}$ at $25^{\circ} \mathrm{C}$ ). An aliquot of $750 \mu 1$ of the upper organic layer was collected and dried out completely by heating at $95^{\circ} \mathrm{C}$ for 20 minute dried material was resuspended in double distilled water.

The negative control of reaction was carried out by adding only substrate, ACE and water. The reaction blank was prepared by mixing substrate, $\mathrm{HCl}$ and ACE. The product hippuric acid was quantified at 228nm. Each sample assay is carried out in triplet and result was represented as a mean of three values \pm Standard Deviation.ACE \% inhibition was calculated using the following formula.

$\%$ ACE inhibiton $=\frac{A_{\underline{c}}-A_{S}}{A_{c_{-}-} A_{b}} \times 100$

Where, $\mathrm{A}_{\underline{c}}=$ Absorbance of control, $A_{s}=$ Absorbance of sample, $A_{b}=$ Absorbance of blank

\section{Results and Discussion}

The dry weight of casein was found to be 2.42 $\mathrm{gm} / 100 \mathrm{ml}$ of cow milk. The total protein was found to be $264 \mu \mathrm{g} / 10 \mu$ lof sodium caseinate (containing $3 \mathrm{~g}$ casein $/ \mathrm{ml}$ of distilled water). The protein was subjected to chymotrypsin degradation for different periods of incubations viz. 60min, 120min, $180 \mathrm{~min}$, $240 \mathrm{~min}$, 300min, $360 \mathrm{~min}$, so as to break the caseinates into peptides having desired biological activities. The peptide hydrolysates thus formed after different incubations, were further analyzed for degree of hydrolysis by Hull's (1947) method using Tyrosine as standard. In general, the $\mathrm{DH}$ goes on increasing continuously with the increase in incubation time, in case of the entire casein sample. The progressions in $\mathrm{DH}$ of cow caseinate by Chymotrypsin were shown in Table1 \& figure 1 .

\section{Antidiabetic assay}

Results vary widely along with hydrolysis time (Table 2\& Figure 2) and a negative correlation between hydrolysis time and $\alpha$ amylase activity was established. In general, maximum inhibitory activity was observed with chymotryptic hydrolysates of cow at 180 minutes of incubation. The highest antidiabetic activity was observed in chymotrypsin hydrolysates in cow caseinafter $3 \mathrm{hr}$ enzymatic treatment i.e. $56.1 \%$, after that it keep on decreasing with increase in incubation time with the enzyme.

\section{Antihypertensive assay}

Casein hydrolysates prepared showed potent ACE inhibitory activity. The inhibition from the peptides derived by treatment of Cow casein with chymotrypsin, was found to be maximum after $6 \mathrm{hr}$ incubation. The highest antihypertensive activity shown by chymotrypsin hydrolysates in cow casein (6hr) was $60.11 \%$. In general, the activity goes on increase along with the incubation period of enzyme hydroyastes (Table $3 \&$ Figure 3).

The degree of hydrolysis (DH) measures the content of peptide bonds cleaved in the substrate by a proteolytic agent (proteases, in the current case): the higher the $\mathrm{DH}$, the higher the content of released amino groups. DH is reported to affect the biological activity of protein hydrolysates. Therefore, the biological activity of peptides depends on the 
protein substrate, enzyme specificity, and hydrolysis conditions (Sarmdi and Ismail, 2010; Hogan et al., 2009; and Zhang \& Zhou, 2010).The DH value increased during hydrolysis time, reaching maximum hydrolysis in $6 \mathrm{~h}$, which is similar to casein hydrolysed by Alcalase (from Bacillus licheniformis). In the current study, the $\mathrm{DH}$ after $6 \mathrm{~h}$ of hydrolysis had not increased significantly. This profile suggests that the enzymes could not further hydrolyze the remaining bonds within the generated peptides, a fact that is directly influenced by enzyme specificity.

\section{Antidiabetic assay}

Digestible carbohydrate containing foods are enzymatically degraded by $\alpha$-amylase and $\alpha$ glucosidase. Inhibition of these enzymes reduced the high post prandial blood glucose peaks in diabetics. For this reason, it is employed as a substrate to evaluate the antidiabetic activity of peptides and protein hydrolysates. In the present study, the activity gradually increased reaching maximum at 3 $\mathrm{hr}$ and then gradually decreased, along with the increase in incubation period in case of enzyme hydrolysates. This could be due to breaking away of amino acids responsible for the activity and formation of smaller peptides having lesser number of such types of amino acids. The results obtained were in accordance with the studies conducted on bioactive peptides derived from different sources by various researchers previously (Ali, H., Houghton, et al., 2006).

\section{Antihypertensive Assay}

Short Peptides containing Proline residues at the C-terminus are thought to be an appropriate ACE inhibitory peptides released on proteolytic hydrolysis. In the present study, there is gradual increase in ACE inhibitory activity along with the increase in incubation time with the enzyme. This could be due to breaking away of inhibitory amino acids and formation of smaller peptides having number of such types of amino acids which are mainly responsible for the ACE inhibition. The results obtained were in accordance with the studies conducted by various researchers previously (Deepthi Koli \& HKL Tandon, 2003)

Table.1 Degree of Hydrolysis of Cow Casein

\begin{tabular}{|c|c|}
\hline Incubation Period (In min) & \% Hydrolysis \\
\hline 60 & 2.5 \\
\hline 120 & 3.5 \\
\hline 180 & 4.0 \\
\hline 240 & 4.4 \\
\hline 300 & 4.7 \\
\hline 360 & 5.1 \\
\hline
\end{tabular}


Table.2 Antidiabetic Status of Cow Casein Hydrolysates Treated With Chymotrypsin for Different Time Intervals

\begin{tabular}{|c|c|}
\hline Incubation Period (In min) & \% Inhibition \\
\hline $\mathbf{6 0}$ & $26.73 \pm 3.52$ \\
\hline $\mathbf{1 2 0}$ & $43.33 \pm 4.71$ \\
\hline $\mathbf{1 8 0}$ & $56.1 \pm 4.71$ \\
\hline $\mathbf{2 4 0}$ & $51.67 \pm 0.742$ \\
\hline $\mathbf{3 0 0}$ & $43.32 \pm 2.35$ \\
\hline $\mathbf{3 6 0}$ & $33.37 \pm 0.21$ \\
\hline
\end{tabular}

Table.3 Antihypertensive Status of Cow Casein Hydrolysates Treated With Chymotrypsin for Different Time Intervals

\begin{tabular}{|c|c|}
\hline Incubation Period (In min) & \% Inhibition \\
\hline $\mathbf{6 0}$ & $20.79 \pm 7.7$ \\
\hline $\mathbf{1 2 0}$ & $29.63 \pm 5.21$ \\
\hline $\mathbf{1 8 0}$ & $36.09 \pm 0.93$ \\
\hline $\mathbf{2 4 0}$ & $45.76 \pm 1.90$ \\
\hline $\mathbf{3 0 0}$ & $52.63 \pm 1.39$ \\
\hline $\mathbf{3 6 0}$ & $60.11 \pm 1.76$ \\
\hline
\end{tabular}

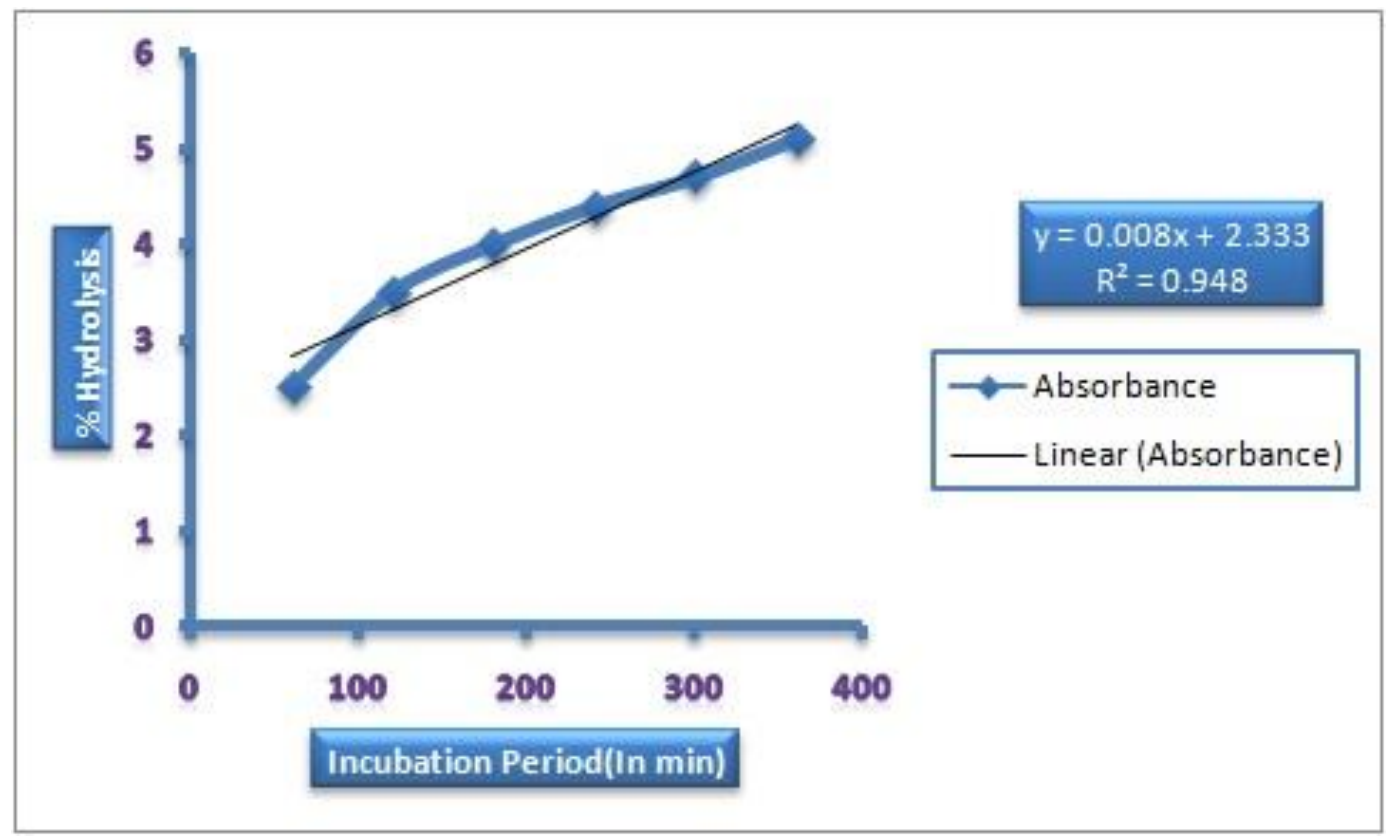

Figure.1 Graph Showing Degree of Hydrolysis of Casein With Chymotrypsin 


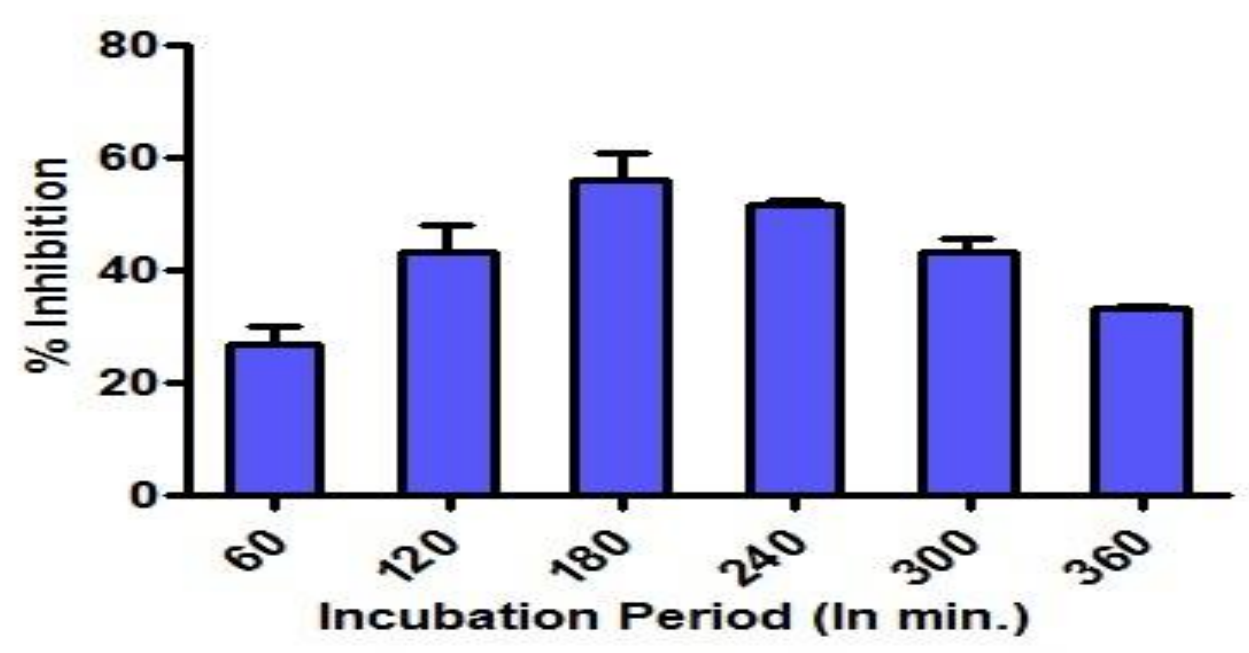

Figure.2 Histogram Showing $\alpha$-Amylase Inhibition Activity of Casein Hydrolysates Obtained by Differential Treatment With Chymotrypsin (the range depicts standard deviation)

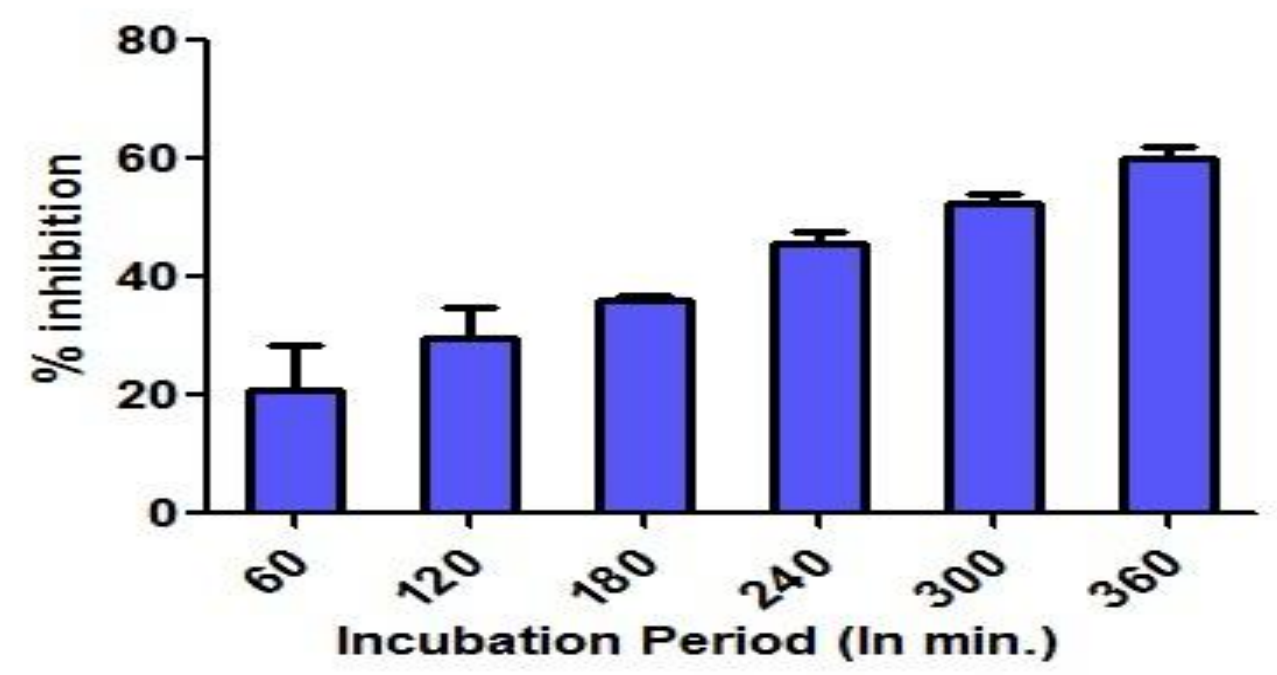

Figure.3 Histogram showing ACE inhibition Activity of Casein Hydrolysates Obtained by Differential Treatment With Chymotrypsin (the range depicts standard deviation)

The present study was aimed on investigating the Antidiabetic and Antihypertensive Bioactive peptides derived from Chymotrypsin treated cow milk. It was observed that casein hydrolysates enzymatically treated at different time intervals were composed of differential peptide formulations which vary in their biogenic properties. Chymotryptic hydrolysates showed highest antidiabetic activity after $3 \mathrm{hr}$ of enzymatic incubation and the highest antihypertensive activity after $6 \mathrm{hr}$ enzymatic treatment. Thus from the data it could be concluded that bioactive peptides released by chymotryptic digestion showed good antidiabetic and antihypertensive activity. Expanding the knowledge about the milk proteins is essential. The most important source of bioactive peptides have been identified in milk protein hydrolysates and metabolic activity under various conditions have been studied by the earlier researchers. 
Antidiabetic and antihypertensive activities affect the digestive, endocrine, cardiovascular, and immune and nervous systems. The potential health benefits of these peptides have been a subject of growing commercial interest in the context of healthpromoting functional foods. Hence, these peptides have immense potential to be incorporated in pharmaceuticals with the purpose of delivering specific health benefits. The multifunctional properties of milk peptides appear to offer considerable potential for the development of many similar products in the near future. Trials on In vivo animal models are required to confirm the activities obtained by in vitro experiments.

\section{Acknowledgments}

The author is thankful to the Dolphin (PG Institute of Biomedical \& Natural Sciences, Dehradun for providing all the necessary chemicals laboratory facility for this research work.

\section{References}

Abubakar,A., Saito,T., Kitazawa,H., Kawai,Y. and Itoh,T. 1998.Structural Analysis of New Antihypertensive Peptides Derived from Cheese Whey Protein by Proteinase K Digestion. J Dairy Sci. 81: 3131-3138.

Ali, H., Houghton, P.J. and Soumyanath, A. 2006. $\alpha$-Amylase Inhibitory Activity of Some Malaysian Plants Used to Treat Diabetes; With Particular Reference to Phyllanthus amarus.J Ethanopharmacol. 107 (3): 449-455.

Bos, C., Gaudichon, C. and Tome, D. 2000. Nutritional \& Physiological Criteria in Assessment of Milk Protein Quality for Human.J Am CollNutr. 19 (Suppl. 2): 191-205.

Collins, R., Pto, R., MacMahon, S., Hebert, P., Fiebach, N.H., Ebertein, K.A.,
Godwin, J., Qizilbash, N., Tayler, J.O. and Hennekens, C.H. 1990. Blood Pressure Stroke and Coronary Heart Diseases. Part 2.The Lancet. 335: 827838.

Cushman, D.W. and Cheung, H.S. 1971.Spectrophotometric Assay and Properties of the Angiotensin Converting Enzyme of Rabbit Lung. Biochem Pharmacol. 20: 1637-1648.

Deepthi, K. and Tandon, H. K. L. 2003.Milk Protein Derived Bioactive Peptides: Significance in Hypertension Reduction. Int J Chem Sci. 1 (3): 165186.

Fitzerald, R.J. and Meisel,H. 2000. Milk Protein Derived Peptides Inhibitors of Angiotensin Converting Enzyme. Brit $\mathbf{J}$ Nutr. 84 (Suppl.1): 533-537.

FitzGerald, R.J. and Meisel,H. 2003.Milk Protein Hydrolysates and Bioactive Peptides. In: Advanced Dairy Chemistry $\left(3^{\text {rd }}\right.$ ed.): In P. F. Fox \& P.L.H. McSweeney (Eds.). Proteins (Vol.1). Kluwer Academic/Plenum Publishers, New York.Pp.: 675-698.

Hernandez-Ledesman, B., Martin-Alvarez, P.J. and Pueyo, E. 2003. Assessment of the Spectrophotometric Method for the Determinattion of AntiotensinConverting Enzyme Activity: Influence of the Inhibition Type. J. Agril and Food Chem. 12: 4175-4179.

Hogan,S., Zhang,L., Li,J.,Wang ,H. andZhou, K.2009. Development of Antioxidant Rich Peptides from Milk Protein by Microbial Proteases and Analysis of Their Effects on Lipid Peroxidation in Cooked Beef. Food Chem.117: 438443.

Hull,M.E. 1947. Studies on Milk Proteins. II. Colorimetric Determination of the Partial Hydrolysis of the Proteins in Milk. J Diary Sci. 30 (11): 881-884.

Kitts D.D. and Weiler,K. 2003. Bioactive Proteins and Peptides from Food 
Sources. Applications of Bioprocesses Used in Isolation and Recovery. Current Pharma Design. 9 (16): 1309-1323.

Kohmura, M., Nio, N., Kubo, K., Minoshima, Y., Munekata, E. and Ariyoshi, Y. 1989.Inhibition of Angiotensin-I Converting Enzyme by Synthetic Peptides of Human $\beta$-casein.AgriBiol Chem. 53: 2107-2114.

Korhonen, H. and Pihlanto,A. 2003.FoodDerived Bioactive PeptidesOpportunities for Designing Future Foods.Current Pharma Design. 9 (16): 1297-1308.

Korhonen, H. and Pihlanto,A. 2006.Bioactive Peptides: Production and Functionality. Int Dairy J. 16 (9): 945-960.

Lowry,O.H., Rosebruough, N.F., Farr, A.C. and Randall, R.I. 1951.Protein Measurement with Folin-Phenol Reagent. J Biol Chem. 193: 265-275.

Martin L. Cross and Gill,H.S. 2000. Immunomodulatory Properties of Milk.Brit J Nutr. 84 (S1): 81-89.

Meisel,H. 1998. Overview on Milk Protein Derived Peptides. Int Dairy J. 8: 363-373.

Pihlanto-Leppala, A., Koskinen, P.,Piilola, K.,Tupasela, T. and Korhonen, $\mathrm{H}$.
2000.Antiotensin I Converting Enzyme Inhibitory Properties of Whey Protein Digests: Concentration and Characterization of Active Peptides. J Dairy Sci. 67: 53-64.

Sarmadi, B.H. and Ismail,A 2010.Antioxidative Peptides from Food Proteins: A Review.Peptides.31: 19491956.

Schlimme,E. and Meisel, H. 1995. Bioactive Peptides Derived from Milk Proteins: Structural, Physiological, and Analytical Aspects. Die Nahrung. 39: 120.https://www.sigmaaldrich.com/techn ical-

documents/protocols/biology/enzymatic -assay-of-alpha-amylase.printview.html

Yamamoto, N., Ejiri, M. and Mizuno, S. 2003.Biogenic Peptides and Their Potential Use. Current Pharma Design. 9 (16): 1345-1355.

Zhang,L.,Li ,J. and Zhou,K. 2010. Chelating and Radical Scavenging Activities of Soy Protein Hydrolysates Prepared from Microbial Proteases and Their Effect on Meat Lipid Peroxidation. Bioresour Technol. 101: 2084-2089.

\section{How to cite this article:}

Santosh Kumar, SumanKumari, Vipan Kumar and Deepak Kumar. 2020. Antidiabetic and Antihypertensive Properties of Chymotrypsin Treated Cow Milk Casein. Int.J.Curr.Microbiol.App.Sci. 9(06): 1246-1255. doi: https://doi.org/10.20546/ijcmas.2020.906.154 